\title{
Performa Produksi dan Analisis Usaha Puyuh (Coturnix coturnix japonica) yang Diberi Substitusi Black Soldier Fly Larvae (BSFL) pada Pakan Komersil
}

\section{Production Performance and Economic Analysis of Quail (Coturnix coturnix japonica) Given Black Soldier Fly Larvae (BSFL) as Commercial Feed Substitution}

\author{
Fithria Nisa Hanifah ${ }^{1 *}$, Koesnoto Soepranianondo ${ }^{2}$, Soeharsono ${ }^{3}$, Anam Al Arif ${ }^{2}$, Widya Paramita Lokapirnasari ${ }^{2}$, \\ Nenny Harijani ${ }^{4}$, Siti Hadijah ${ }^{1}$, Mariana Ruth Theresia Hutabarat ${ }^{1}$ \\ ${ }^{1}$ Program Magister, Agribisnis Veteriner, Fakultas Kedokteran Hewan, Universitas Airlangga \\ ${ }^{2}$ Departemen Peternakan, Fakultas Kedokteran Hewan, Universitas Airlangga \\ ${ }^{3}$ Departemen Anatomi, Fakultas Kedokteran Hewan, Universitas Airlangga \\ ${ }^{4}$ Departemen Kesehatan Masyarakat Veteriner, Fakultas Kedokteran Hewan, Universitas Airlangga \\ ${ }^{1,2,3,4}$ Kampus C, Jl. Mulyorejo, Kota Surabaya, Jawa Timur, Indonesia \\ *Email: fnh.vet@gmail.com
}

Naskah diterima: 27 Agustus 2019, direvisi: 11 September 2019, disetujui: 15 Oktober 2019

\begin{abstract}
Black Soldier Fly Larvae (BSFL) is an alternative protein source for livestock. This research aimed to know the effectiveness of BSFL for commercial feed substitution, related to production, productivity, and profitability in quail farm. This study used 80 quails which divided into 4 groups and each group consist of 20 quails. The treatments contained BSFL substitution with different composition, control group (P0) was given $100 \%$ commercial feed, (P1) was given a 5\% BSFL substitution, (P2) was given a 10\% BSFL substitution and (P3) was given a $20 \%$ BSFL substitution. Contribution margin (CM) analysis was used to determine the yields of the groups in this study. Results showed that the highest feed consumption rate is in P3, production (egg in total and weight), productivity and yields in P3 is the highest, although there's no difference between P0, P2 and P3 based on the analysis MANOVA. BSFL substitution at $20 \%$ is recommended to the farmers to increase profits.
\end{abstract}

Key words: BSFL; Egg mass; Egg production; Feed consumption; Quail Productivity

\begin{abstract}
Black Soldier Fly Larvae (BSFL) adalah sumber protein alternatif untuk ternak. Penelitian ini bertujuan untuk mengetahui efektivitas BSFL sebagai substitusi pakan komersial, terkait dengan produksi, produktivitas, dan profitabilitas di peternakan puyuh. Penelitian ini menggunakan 80 burung puyuh yang dibagi menjadi 4 perlakuan yang terdiri dari 20 ekor. Perlakuan mengandung substitusi BSFL dengan komposisi berbeda, perlakuan kontrol (P0) diberi pakan komersial 100\%, (P1) diberi substitusi BSFL 5\%, (P2) diberi substitusi BSFL 10\% dan (P3) diberi $20 \%$ Substitusi BSFL. Analisis margin kontribusi (CM) digunakan untuk menentukan keuntungan pada perlakuan dalam penelitian ini. Hasil menunjukkan bahwa tingkat konsumsi pakan lebih tinggi di P3, produksi (jumlah dan berat telur), produktivitas dan pendapatan di P3 adalah yang tertinggi, meskipun tidak ada perbedaan antara P0, P2 dan P3 berdasarkan analisis MANOVA. Substitusi BSFL sebanyak 20\% direkomendasikan kepada petani untuk meningkatkan keuntungan.
\end{abstract}

Kata Kunci: berat telur; BSFL; konsumsi pakan; produksi telur; produktivitas puyuh 


\section{Pendahuluan}

Meningkatnya minat masyarakat terhadap telur puyuh merupakan peluang tersendiri bagi peternak puyuh untuk mengembangkan bisnisnya dan mengoptimalkan produksi ternaknya. untuk mengembangkan bisnisnya dan mengoptimalkan produksi ternaknya. Pakan yang berkualitas merupakan salah satu faktor yang menentukan keberhasilan suatu peternakan dan sekaligus menjadi komponen pengeluaran terbesar dalam suatu kegiatan usaha ternak unggas, yaitu sebesar $50-70 \%$ dari biaya total (Veldkamp and Bosch, 2015), dan protein merupakan komponen penting dalam suatu formulasi pakan. Protein dibutuhkan oleh tubuh ternak dalam metabolisme vital, yang berkaitan dengan enzim, hormon, dan antibodi (Beski et al., 2015).

Protein asal insekta dinilai lebih ekonomis serta ramah lingkungan. Menurut penelitian yang telah dilakukan oleh Wardhana (2016) mengenai penggunaan insekta sebagai sumber protein pakan, insekta memiliki efisiensi konversi pakan yang tinggi, memungkinkan untuk diproduksi secara masal. Insekta juga memiliki nilai positif lain bagi lingkungan, mengurangi limbah organik yang berpotensi mencemari lingkungan (Li et al., 2011).

Black Soldier Fly (BSF) atau yang biasa disebut dengan lalat tentara hitam ini berasal dari Amerika, namun saat ini sudah tersebar di wilayah tropis dan sub tropis (Čičková et al., 2015) termasuk Indonesia. Penelitian mengenai penggunaan larva dari BSF (BSFL) dalam pakan unggas sebelumnya sudah pernah dilakukan pada ayam broiler (Okah dan Onjuwuriani, 2012; Hopeley, 2015;), burung puyuh pedaging (Cullere, 2016) dan burung puyuh petelur (Widjiastuti, dkk. 2014) sebagai pengganti sumber protein dalam pakan. Tingginya potein dan kandungan asam amino yang tidak jauh berbeda dengan sumber pakan protein lainnya membuat BSFL memiliki potensi sebagai pengganti sumber protein (Wardhana, 2016). Serangga dapat digunakan sebagai bahan pakan sumber protein bagi ternak, sebagai opsi alternatif dari tepung ikan dan kacang kedelai (Vrabec et al., 2015). Hopley (2015) menyebutkan bahwa serangga merupakan bagian pakan alami untuk unggas khususnya. Selain protein, serangga juga mengandung lemak, mineral dan vitamin yang tinggi. Berdasarkan penelitian yang telah dilakuan oleh Hopley (2015) penggunaan BSFL dalam pakan memberikan efek positif terhadap kualitas dan produktivitas telur.
Berbagai variasi penggunaan BSFL sebagai bahan substitusi parsial (terhadap komponen protein) telah banyak dilakukan pada berbagai unggas dan memberikan respon positif, namun penggunaan BSFL sebagai bahan substitusi dari pakan komersil masih belum dilaporkan. Penelitian ini bertujuan untuk melihat respon konsumsi pakan, produksi, produktivitas serta bobot telur yang dihasilkan dari burung puyuh (Coturnix coturnix japonica) yang diberi pakan dengan substitusi pakan komersil dengan BSFL sebanyak 5\%, 10\% dan $20 \%$.

\section{Materi dan Metode}

\section{Kelayakan Etik}

Penelitian ini telah mendapatkan persetujuan keterangan kelaikan etik (ethical clearance) dari komisi Etik Penelitian, Universitas Brawijaya No.1163-KEPUB.

\section{Lokasi dan Waktu Penelitian}

Penelitian ini dilaksanakan selama 6 minggu, pada 15 mei - 26 juni 2019. Analisis proksimat dan persiapan ransum dilaksanakan di Laboratorium Pakan Ternak, Departemen Peternakan, Fakultas Kedokteran Hewan Universitas Airlangga. Pemeliharaan hewan coba dilaksanakan di peternakan A farm, di Mijen, Semarang, Jawa Tengah.

\section{Bahan dan Instrumen Penelitian}

Bahan - bahan yang digunakan dalam penelitian ini adalah pakan komersil Evialis R5 Premium (PT. Welgro Feedmill Indonesia, dibawah lisensi Neovia, Perancis), BSFL, desinfektan menggunakan Rodalon ${ }^{\circledR}$, air gula dengan perbandingan 20 gram gula dalam 1 liter air minum. Hewan coba yang digunakan sebanyak 80 ekor burung puyuh betina petelur umur 11 minggu asal kota Semarang.

Alat - alat yang digunakan dalam penelitian ini adalah ember, saringan besar, pengaduk, timbangan digital, termometer ruangan, hygrometer, alat - alat pembersih kandang, hand sprayer, masker, gloves, lampu penerangan 40 watt, tempat pakan dan minum dari bahan plastik dan 40 unit kandang baterai dibuat dari kayu, bambu dan kawat ram. Tiap unit berukuran panjang $30 \mathrm{~cm} \times$ lebar $30 \mathrm{~cm} \times$ tinggi $30 \mathrm{~cm}$ tiap unit berisi dua ekor burung puyuh. 


\section{Pelaksanaan Penelitian}

Kandang terlebih dahulu didesinfeksi dengum Rodalon ${ }^{\circledR}$ dengan dosis $15 \mathrm{ml} / 10$ liter air sebelum digunakan. Burung puyuh diberi minum air gula dengan perbandingan 20 gram gula dalam 1 liter air minum pada hari pertama kedatangan. Sebanyak 80 ekor burung puyuh diacak secara random menjadi 4 perlakuan yang terdiri dari 20 ekor.

Perlakuan berupa substitusi BSFL dalam pakan dengan beberapa konsentrasi, perlakuan kontrol (P0) diberi $100 \%$ pakan komersial, perlakuan (P1) diberi substitusi BSFL 5\%, perlakuan (P2) diberi substitusi BSFL $10 \%$ dan perlakuan (P3) diberi substitusi $20 \%$ BSFL. Burung puyuh mulai dipelihara pada umur 11 minggu, adaptasi dua minggu kemudian mulai diberi perlakuan pada umur 13 minggu dan dipelihara sampai berumur 17 minggu.

Penetapan biosekuriti diberlakukan dengan mengharuskan setiap orang yang masuk harus menggunakan pakaian dan alas kaki khusus dan sudah disemprot desinfektan. Pengecekan kesehatan puyuh, pembersihan kotoran, pengukuran suhu dan kelembaban kandang dilakukan setiap hari. Pembersihan tempat makan dan minum juga dilakukan setiap hari. Desinfeksi kandang dilakukan dua kali seminggu.

Perhitungan data berupa konsumsi pakan, egg mass (EM) dan persentase Quail Day Production (QDP) dilaksanakan setiap minggu. Koleksi data jumlah konsumsi pakan, berat telur dan produksi telur dilakukan setiap hari. Perhitungan data berupa konsumsi pakan, egg mass (EM) dan persentase Quail Day Production (QDP) dilaksanakan setiap minggu. Penghitungan jumlah konsumsi pakan dilakukan dengan formula:

Konsumsi Pakan $=\frac{\text { Pakan yang diberikan }- \text { Pakan sisa }}{\text { Lama pemeliharaan }}$

Persentase QDP dihitung dalam periode minggu pada setiap ulangan, berikut adalah formula yang digunakan untuk menghitung QDP :
Konsumsi Pakan $=\frac{\text { Pakan yang diberikan }- \text { Pakan sisa }}{\text { Lama pemeliharaan }}$

Penghitungan EM dilakukan dalam periode mingguan, berikut formula yang digunakan dalam menghitung EM :

$$
\mathrm{EM}=\frac{\text { Bobot telur }}{\text { Jumlah telur }}
$$

Analisa usaha dilakukan dengan cara menghitung contribution margin (CM). Perhitungan CM dilakukan pada akhir penelitian, formula yang digunakan dalam perhitungan $\mathrm{CM}$ dituliskan sebagai berikut:

\section{Analisis Data Statistik}

Data hasil eksperimen yang diperoleh kemudian dianalisa menggunakan analisis ragam peubah ganda (MANOVA) untuk membuktikan adanya perbedaan yang nyata dari perlakuan yang diberikan. Apabila diperoleh hasil yang berbeda atau berbeda sangat nyata maka dilanjutkan dengan uji jarak berganda Duncan (Kusriningrum, 2008). Analisis statistik menggunakan program SPSS for Windows 23.0. Data analisis finansial dan usaha dijabarkan secara deskriptif.

\section{Hasil dan Pembahasan}

\section{Analisis Proximat Perlakuan}

Analisis proximat dilakukan untuk mendapatkan nilai dari kandungan nutrisi pada tiap perlakuan. Berikut adalah hasil mengenai hasil analisis proximat :

\section{Konsumsi Pakan}

Penghitungan konsumsi pakan didapatkan dari pengurangan jumlah pakan yang diberikan dengan jumlah pakan yang tidak dikonsumsi selama penelitian kemudian dibagi dengan jumlah hari lama pemeliharaan (28 hari). Hasil olah data statistik mengenai konsumsi pakan selama periode penelitian per individu perlakuan terdapat pada tabel 2.

Tabel 1. Analisis Proximat BSFL dan Pakan Perlakuan yang Digunakan Selama Periode Penelitian

\begin{tabular}{ccccccccc}
\hline Bahan & $\begin{array}{c}\text { Bahan Kering } \\
\mathbf{( \% )}\end{array}$ & $\begin{array}{c}\text { Abu } \\
\mathbf{( \% )}\end{array}$ & $\begin{array}{c}\text { Protein Kasar } \\
(\mathbf{\%})\end{array}$ & $\begin{array}{c}\text { Serat Kasar } \\
\mathbf{( \% )}\end{array}$ & $\begin{array}{c}\text { Ca } \\
(\%)\end{array}$ & $\begin{array}{c}\text { BETN } \\
(\%)\end{array}$ & $\begin{array}{c}\text { Energi Metabolisme } \\
(\text { Kcal/Kg) }\end{array}$ & $\begin{array}{c}\text { Lemak Kasar } \\
(\%)\end{array}$ \\
\hline BSFL & 29,58 & 3,19 & 10,46 & 10,56 & 0,859 & 1,75 & 698,15 & 3,60 \\
P0 & 91,87 & 12,94 & 20,11 & 3,58 & 4,93 & 45,10 & 3066,35 & 10,11 \\
P1 & 88,75 & 12,45 & 19,62 & 3,93 & 4,72 & 42,93 & 2947,65 & 9,78 \\
P2 & 85,64 & 11,96 & 19,14 & 4,27 & 4,52 & 40,76 & 2829,21 & 9,45 \\
P3 & 79,41 & 10,99 & 18,18 & 4,97 & 4,11 & 36,43 & 2592,43 & 8,80 \\
\hline
\end{tabular}


Tabel 2. Nilai Rata-rata dan Simpangan Baku Konsumsi Pakan Tiap Individu Perlakuan Selama Periode Penelitian

\begin{tabular}{lc}
\hline Perlakuan & Konsumsi Pakan (g/ekor/periode) \\
\hline P0 & $653,90 \pm 23,47^{\mathrm{bc}}$ \\
P1 & $646,30 \pm 23,58^{\mathrm{b}}$ \\
P2 & $629,56 \pm 8,56^{\mathrm{a}}$ \\
P3 & $668,52 \pm 6,87^{\mathrm{c}}$ \\
\hline
\end{tabular}

Keterangan: Notasi (superscript) yang berbeda menunjukkan perbedaan nyata $(\mathrm{p}<0,05)$

Hasil pada tabel 2 menunjukkan bahwa adanya perbedaan yang signifikan antara P1, P2 dan P3, sedangkan $\mathrm{P} 0$ tidak menunjukkan perbedaan nyata terhadap P1 dan P3. Terdapat beberapa faktor yang sangat mempengaruhi tingkat konsumsi pakan, diantaranya kualitas pakan, kuantitas pakan, palatabilitas pakan, serta kondisi individu puyuh yang meliputi umur dan ukuran badan (Dewi dan Setiohadi, 2010). Perbedaan konsumsi pakan dalam penelitian ini disebabkan oleh adanya perbedaan kualitias pakan (nutrisi yang terdapat dalam masing-masing pakan). Merujuk pada tabel 1 mengenai nutrisi dalam pakan setiap perlakuan, terlihat adanya perbedaan kandungan protein dan energi metabolisme pada tiap perlakuan. Kandungan protein dan energi metabolisme yang terdapat dalam pakan sangat berpengaruh terhadap tingkat konsumsinya (Suroso,2016) karena unggas akan berhenti makan apabila energi metabolismenya sudah terpenuhi.

Faktor lain yang menyebabkan terjadinya perbedaan tingkat konsumsi pakan adalah kandungan kitin dalam BSFL. Kitin adalah polimer linier, tidak beracun, dan merupakan unsur utama eksoskeleton pada serangga. Kandungan kitin menyebabkan kurangnya efisiensi pakan, sehingga konsumsi pakan meningkat (Amao et al. 2010). Hal serupa juga dituliskan oleh Belluco et al., (2013), kitin menyebabkan penurunan kecernaan terhadap bahan pakan yang berasal dari serangga. Konsumsi pakan tertinggi dalam penelitian ini ditunjukkan pada P3 yang mengandung BSFL sebanyak $20 \%$ dari total pakan.

\section{Produksi, Produktivitas dan Bobot Telur}

Hasil produksi telur selama penelitian dihitung dari jumlah (butir) dan berat telur ( $\mathrm{kg}$ ) yang dihasilkan. Untuk perhitungan jumlah pembulatan dilakukan dengan cara apabila hasil $>0,5$ akan dibulatkan menjadi 1 telur. Tabel 3 menyajikan rerata hasil produksi per ekor puyuh selama periode penelitian:
Tabel 3. Rerata dan Simpangan Baku Hasil Produksi per Ekor Selama Periode Penelitian

\begin{tabular}{llll}
\hline Perlakuan & $\begin{array}{l}\text { Jumlah } \\
\text { (butir/ekor) }\end{array}$ & $\begin{array}{l}\text { Pembulatan } \\
\text { jumlah (butir) }\end{array}$ & $\begin{array}{l}\text { Berat total telur } \\
\text { (kg/ekor) }\end{array}$ \\
\hline P0 & $46,70 \pm 4,59^{\mathrm{b}}$ & $47 \pm 5$ & $0,47 \pm \mathbf{0 , 0 4} 4^{\mathrm{b}}$ \\
P1 & $37,10 \pm 4,81^{\mathrm{a}}$ & $37 \pm 5$ & $0,38 \pm 0,05^{\mathrm{a}}$ \\
P2 & $44,30 \pm 4,42^{\mathrm{b}}$ & $44 \pm 4$ & $0,46 \pm 0,04^{\mathrm{b}}$ \\
P3 & $46,80 \pm 3,15^{\mathrm{b}}$ & $47 \pm 3$ & $0,49 \pm 0,03^{\mathrm{b}}$ \\
\hline
\end{tabular}

Keterangan: ${ }^{\mathrm{a}, \mathrm{b}}$ Notasi (superscript) yang berbeda menunjukkan perbedaan nyata $(\mathrm{p}<0,05)$.

Tabel 4. Rerata dan Simpangan Baku Hasil Produktivitas (QDP) Tiap Perlakuan Selama Periode Penelitian.

\begin{tabular}{ll}
\hline Perlakuan & Produktivitas $(\%)$ \\
\hline P0 & $83,39 \pm 0,81^{\mathrm{b}}$ \\
P1 & $66,24 \pm 0,85^{\mathrm{a}}$ \\
P2 & $79,10 \pm 0,79^{\mathrm{b}}$ \\
P3 & $83,57 \pm 0,56^{\mathrm{b}}$ \\
\hline
\end{tabular}

Keterangan: ${ }^{\mathrm{a}, \mathrm{b}}$ Notasi (superscript) yang berbeda menunjukkan perbedaan nyata $(\mathrm{p}<0,05)$.

Produktivitas burung puyuh dapat dilihat melalui persentase QDP. Tabel 4 menyajikan hasil persentase QDP pada tiap perlakuan selama periode penelitian :

Pada tabel 3 dan 4 tidak terlihat adanya perbedaan yang signifikanantara P0,P2 dan P3. Perbedaan produksi dan produktivitas burung puyuh diyakini disebabkan oleh faktor pakan (nutrisi dalam pakan) sehingga manajemen pakan sangat berpengaruh terhadap tingkat produksi burung puyuh. Manajemen pakan terdiri atas beberapa komponen yaitu ketersediaan pakan, kualitas serta kuantitas pakan (Rahmasari et al. 2014). Merujuk pada tabel 1 mengenai nutrisi dalam pakan setiap perlakuan, serta tabel 2 mengenai tingkat konsumsi pakan, perbedaan nutrisi yang terkandung dalam pakan dan tingkat konsumsi pakan berpengaruh terhadap jumlah komponen nutrisi yang diperoleh ternak.

Brand et al., (2003) menyebutkan bahwa faktor utama yang mempengaruhi produksi telur adalah jumlah dari konsumsi pakan dan nutrisi yang terdapat didalam pakan tersebut. Protein merupakan salah satu komponen terpenting dalam pakan yang berimbas langsung pada pertumbuhan badan dan reproduksi ternak (Permatahati dkk, 2018). Kandungan protein, terutama bagian asam amino (AA) yang terdapat didalamnya mampu mempengaruhi komponen sistem imun yang berhubungan dengan kesehatan burung puyuh (Abbasi et.al., 2014). Ketersediaan AA dalam 
pakan juga mempengaruhi produksi telur, AA akan membentuk protein yang ada dalam telur (Santos et.al., 2016).

Protein terdiri dari AA yang dibutuhkan untuk mempertahankan fungsi tubuh, pertumbuhan dan reproduksi. Asam amino terbagi menjadi dua golongan yaitu asam amino esensial (EAA) dan asam amino non-esensial (NEAA). Komponen NEAA diantaranya adalah glutamin, glutamat, prolin, glisin dan arginin (Wu, 2013) dapat ditransmisikan dari AA lain oleh tubuh hewan, oleh sebab itu, suplementasi NEAA tidak diperlukan. Berbeda dengan NEAA, seperti cysteine, histidine, isoleucine, leucine, lysine, methionine, phenylalanine, threonine, tryptophan, tyrosine, and valine tidak disintesis dalam tubuh, sehingga diperlukan asupan AAE dari luar tubuh (Wu, 2014). Kandungan protein dalam pakan asal serangga dinilai mampu untuk memenuhi kebutuhan komposisi AA pada ternak (Józefiak \& Engberg, 2015). Tabel 5 menyajikan rerata bobot telur yang dihasilkan perlakuan selama periode penelitian.

Pada tabel 5 tidak terlihat adanya perbedaan yang signifikan antara P0, P2 dan P3. Bobot telur dalam penelitian ini lebih besar apabila dibandingkan dengan hasil penelitian Tugiyanti, dkk (2017) yaitu 9,36 \pm $0,40-9,73 \pm 0,19 \mathrm{~g} /$ butir. Perbedaan bobot telur dalam penelitian ini diyakini disebabkan oleh perbedaan kadar protein yang terkandung dalam pakan pada masing-masing perlakuan (Permatahati dkk, 2018) serta tingkat konsumsi pakan (Brand et al., 2003).

Protein dalam pakan mempengaruhi sintesis protein pada albumin dan kuning telur, dua komponen yang merupakan komponen terbesar penentuan bobot telur (Tugiyanti dkk, 2017). Protein yang cukup dalam pakan (minimal 17\% berdasarkan SNI 01-3905-2006) dapat memenuhi kebutuhan organ reproduksi burung puyuh, sehingga dapat bersiklus lebih baik dan tepat waktu sehingga mampu meningkatkan keuntungan bagi peternak. Protein akan digunakan untuk

Tabel 5. Rerata dan Simpangan Baku Bobot Telur Tiap Perlakuan Selama Periode Penelitian

\begin{tabular}{ll}
\hline Perlakuan & Bobot Telur $(\mathrm{g})$ \\
\hline P0 & $10,20 \pm \mathbf{0 , 2 6 ^ { \mathrm { a } }}$ \\
P1 & $10,34 \pm 0,15^{\mathrm{a}}$ \\
P2 & $10,57 \pm 0,58^{\mathrm{b}}$ \\
P3 & $10,65 \pm 0,10^{\mathrm{b}}$ \\
\hline
\end{tabular}

Keterangan: a,b Notasi (superscript) yang berbeda menunjukkan perbedaan nyata $(\mathrm{p}<0,05)$. menyediaan hormon - hormon dalam tubuh burung puyuh untuk produksi telur (Achmad, 2011). Protein juga mengandung komponen AA juga berpengaruh terhadap bobot telur. Alagawany dan Mahrose (2014) menyebutkan bahwa AA, terutama lysine dan methionine merupakan faktor utama dalam penentuan bobot telur. Lysine dan methionine dapat menstimulasi sekresi insulin dari pankreas dengan cara agregrasi dalam plasma yang akan melepaskan AA dari tempat penyimpanannya, kemudian memicu sintesa protein.

\section{Analisis Finansial}

Komponen analisis finansial usaha yang diperhitungkan dalam penelitian ini adalah biaya variabel dan pendapatan, dalam penelitian ini biaya total tidak dihitung karena dianggap sama pada tiap perlakuan.

\section{Biaya Variabel}

Biaya variabel yang terdapat dalam penelitian ini terdiri dari biaya pakan komersil dan BSFL. Biaya variabel dalam penelitian ini selama periode penelitian dirangkum dalam tabel 6 .

Tabel 6. Harga Pakan Per Kg tiap Perlakuan Selama Periode Penelitian

\begin{tabular}{lllll}
\hline Deskripsi & P0 (Rp) & P1 (Rp) & P2(Rp) & P3 (Rp) \\
\hline Pakan komersil & $6.000,00$ & $5.700,00$ & $5.400,00$ & $4.800,00$ \\
BSFL & 0 & 250,00 & 500,00 & $1.000,00$ \\
\hline Total & $6.000,00$ & $5.950,00$ & $5.900,00$ & $5.800,00$ \\
\hline
\end{tabular}

Biaya konsumsi didapatkan dari rerata konsumsi pakan dikalikan dengan harga pakan pada tiap perlakuan. Tabel 7 menyajikan rerata biaya konsumsi pakan yang diberikan selama periode penelitian pada unit perlakuan.

Tabel 7. Rerata dan Simpangan Baku Biaya Konsumsi Pakan tiap Perlakuan Selama Periode Penelitian

\begin{tabular}{cc}
\hline Perlakuan & Biaya Konsumsi (Rp) \\
\hline P0 & $3920,30 \pm 145,59^{\mathrm{b}}$ \\
P1 & $3845,51 \pm 140,35^{\mathrm{b}}$ \\
P2 & $3714,41 \pm 50,52^{\mathrm{a}}$ \\
P3 & $3839,42 \pm 39,89^{\mathrm{b}}$ \\
\hline
\end{tabular}

Keterangan: ${ }^{\mathrm{a}, \mathrm{b}}$ Notasi (superscript) yang berbeda menunjukkan perbedaan nyata $(\mathrm{p}<0,05)$.

Pada tabel 7 tidak terlihat adanya perbedaan yang signifikan antara P0, P2 dan P3. Merujuk pada tabel 6 mengenai harga pakan tiap perlakuan dan tabel 
Tabel 8. Rerata dan Simpangan Baku Pendapatan tiap Perlakuan Berdasarkan Harga Per Butir

\begin{tabular}{cc}
\hline Perlakuan & Pendapatan $(\mathrm{Rp})$ \\
\hline P0 & $16.345,00 \pm 1.608,56^{\mathrm{b}}$ \\
P1 & $12.985,00 \pm 1.686,22^{\mathrm{a}}$ \\
P2 & $15.505,00 \pm 1.548,19^{\mathrm{b}}$ \\
P3 & $16.380,00 \pm 1.104,33^{\mathrm{b}}$ \\
\hline
\end{tabular}

Keterangan: a,b, Notasi (superscript) yang berbeda menunjukkan perbedaan nyata $(\mathrm{p}<0,05)$.

Tabel 9. Rerata dan Simpangan Baku Pendapatan tiap Perlakuan Berdasarkan Harga Per Kg

\begin{tabular}{cc}
\hline Perlakuan & Pendapatan $(\mathrm{Rp})$ \\
\hline P0 & $12.858,00 \pm 1.243,00^{\mathrm{b}}$ \\
P1 & $10.362,78 \pm \mathbf{1 . 3 5 9 , 3 1}^{\mathrm{a}}$ \\
P2 & $12.644,76 \pm 1.208,99^{\mathrm{b}}$ \\
P3 & $13.465,57 \pm 897,92^{\mathrm{b}}$ \\
\hline
\end{tabular}

Keterangan: a,b, Notasi (superscript) yang berbeda menunjukkan perbedaan nyata $(\mathrm{p}<0,05)$.

2 mengenai tingkat konsumsi pakan tiap individu selama periode penelitian, terlihat bahwa P3 memiliki konsumsi pakan tertinggi, namun biaya pakan per-Kg terendah, sehingga biaya konsumsi tertinggi adalah P0.

\section{Pendapatan}

Pendapatan dalam penelitian ini berasal dari penjualan telur puyuh. Pendapatan dipengaruhi oleh produksi, semakin tinggi produksi yang dihasilkan, maka pendapatan akan semakin bertambah, Terdapat dua harga jual produk yang diaplikasikan dalam penelitian ini, yaitu harga per butir dan harga per $\mathrm{Kg}$. Harga per butir telur adalah Rp.350,00 dan harga per $\mathrm{Kg}$ adalah Rp.27.000,00. Harga per butir diberikan pada kostumer eceran (direct marketing) dan harga per Kg diberikan pada kostumer yang membeli dalam jumlah banyak (wholeselling). Berikut adalah tabel mengenai pendapatan berdasarkan harga jual per butir dan per $\mathrm{Kg}$ selama periode penelitian:

Pendapatan atas harga jual per $\mathrm{Kg}$ didapatkan dari mengalikan total produksi telur $(\mathrm{Kg})$ dengan harga telur per Kg. Berdasarkan dari kedua tabel tersebut, pendapatan terbesar didapatkan dari penjualan per butir pada P3, baik dalam harga per butir maupun per Kg. Merujuk pada tabel 3 menyajikan hasil produksi selama periode penelitian, produksi telur tertinggi terdapat pada $\mathrm{P} 3$, sehingga pendapatan harga per butir tertinggi berada pada $\mathrm{P} 3$. Berdasarkan tabel 8 dan 9 tidak ada perbedaan yang signifikan antara P0, P2 dan
P3.

\section{Contribution Margin (CM)}

Contribution Margin (CM) merupakan alat bantu yang dapat digunakan untuk menganalisis tingkat keuntungan dalam suatu produksi (Dewi dkk, 2017). Contribution Margin didapatkan dengan cara mengurangi jumlah pendapatan total dengan biaya variabel (biaya konsumsi). Hasil perhitungan tersebut adalah proyeksi kontribusi keuntungan dalam suatu unit usaha. Unit usaha merupakan gambaran mengenai mengenai total pengeluaran yang dihubungkan dengan kondisi keuntungan yang diperoleh dalam suatu usaha. Contribution Margin dalam penelitian ini dihitung dalam dua harga, yaitu harga perbutir dan harga per $\mathrm{Kg}$. Berikut adalah tabel mengenai CM berdasarkan harga jual per $\mathrm{Kg}$ dan per butir selama periode penelitian (tabel 10) :

Perhitungan $\mathrm{CM}$ atas harga per butir didapatkan dari mengurangi pendapatan atas harga per butir dengan biaya variabel total dalam penelitian ini. Merujuk pada tabel 7 tabel mengenai rerata biaya konsumsi pakan bulanan pada unit perlakuan dan tabel 8 mengenai pendapatan atas harga per butir, terlihat bahwa pendapatan tertinggi dan biaya terendah berada pada P3. Hasil pada tabel 7 dan tabel 8 berpengaruh terhadap tabel 10. Keuntungan tinggi ditunjukkan pada $\mathrm{P}$, namun, tidak ada perbedaan nyata antara $\mathrm{P}$, P2 dan P3. Berikut adalah tabel mengenai Rerata dan

Tabel 10. Rerata dan Simpangan Baku CM Berdasarkan Harga Per Butir Tiap Perlakuan

\begin{tabular}{cc}
\hline Perlakuan & Contribution Margin $(\mathrm{Rp})$ \\
\hline P0 & $12.434,70 \pm 1.651,35^{\mathrm{b}}$ \\
P1 & $9.139,49 \pm 1.702,30^{\mathrm{a}}$ \\
P2 & $11.790,58 \pm 1.532,04^{\mathrm{b}}$ \\
P3 & $12.440,39 \pm 1.147,91^{\mathrm{b}}$ \\
\hline
\end{tabular}

Keterangan: ${ }^{\mathrm{a}, \mathrm{b},}$, Notasi (superscript) yang berbeda menunjukkan perbedaan nyata $(\mathrm{p}<0,05)$.

Tabel 11. Rerata dan Simpangan Baku CM Berdasarkan Harga per Kg Tiap Perlakuan

\begin{tabular}{ll}
\hline Perlakuan & Contribution Margin $(\mathrm{Rp})$ \\
\hline P0 & $8.938,28 \pm 1.283,37^{\mathrm{b}}$ \\
P1 & $6.517,27 \pm 1.373,82^{\mathrm{a}}$ \\
P2 & $8.930,35 \pm 1.193,05^{\mathrm{b}}$ \\
P3 & $9.525,97 \pm 944,96^{\mathrm{b}}$ \\
\hline
\end{tabular}

Keterangan: ${ }^{\text {a,b, }}$ Notasi (superscript) yang berbeda menunjukkan perbedaan nyata $(\mathrm{p}<0,05)$. 
simpangan baku CM berdasarkan harga per Kg Tiap Perlakuan Selama Periode Penelitian:

Perhitungan $\mathrm{CM}$ atas harga per $\mathrm{Kg}$ didapatkan dari mengurangi pendapatan atas harga per $\mathrm{Kg}$ dengan biaya variabel total. Merujuk pada tabel 7 tabel mengenai rataan biaya konsumsi pakan bulanan pada unit perlakuan dan tabel 9 mengenai pendapatan atas harga per $\mathrm{Kg}$, terlihat bahwa pedapatan tertinggi dan biaya terendah berada pada P3. Hasil pada tabel 7 dan tabel 9 berpengaruh terhadap tabel 11 . Keuntungan tinggi ditunjukkan pada $\mathrm{P} 3$, namun, tidak ada perbedaan nyata antara P0, P2 dan P3.

Berdasarkan hasil pada tabel 10 dan 11, dapat dikatakan bahwa seluruh perlakuan dalam penelitian ini tidak ada yang mengalami kerugian. Contribution margin tertinggi diperoleh pada P3 dengan cara penjualan telur per butir, sedangkan $\mathrm{CM}$ terendah terjadi pada $\mathrm{P} 1$ dengan cara penjualan telur per $\mathrm{Kg}$. Perlakuan yang mendapat CM tertinggi, disebabkan oleh tingginya harga jual dan produksi, sehingga penerimaan lebih besar dan mampu menutup biaya produksi yang dibutuhkan dibandingkan dari perlakuan lainnya.

\section{Kesimpulan}

Berdasarkan penelitian yang telah dilakukan maka dapat disimpulkan bahwa substitusi pakan komersial dengan BSFL hingga 20\% mampu meningkatkan konsumsi pakan, dan mampu menyamai hasil produksi, produktivitas serta bobot telur dari pakan komersil.

\section{Ucapan Terima Kasih}

Terimakasih kepada dosen pembimbing dan pihak peternakan yang telah bersedia mendukung pelaksanaan penelitian ini.

\section{Daftar Pustaka}

Abbasi, M. A., A. H. Mahdavi, A. H. Samie, and R. Jahanian. (2014). Effects of different levels of dietary crude protein and threonine on performance, humoral immune responses and intestinal morphology of broiler chicks. R. Braz. Ci. Solo 16:35-44. https://doi.org/10.1590/ S1516-635X2014000100005.

Achmad, D. H. (2011). Performa produksi burung puyuh (coturnix-coturnix japonica) yang diberi pakan dengan suplementasi omega-3. Skripsi. Intitut Pertanian Bogor

Amao, O., Oladunjoye, I., Togun, V., Olubajo, K. and Oyaniyi, O. (2010). Effect of Westwood (Cirina forda) larva meal on the laying performance and egg characteristics of laying hen in a tropical environment. International Journal of Poultry Science. 9:450-454.

Belluco, S., Losasso, C., Maggioletti, M., Alonzi, C.C., Paoletti, M.G. and Ricci, A. (2013). Edible insects in a food safety and nutritional perspective: a critical review. Comprehensive Reviews in Food Science and Food Safety. 12: 296-313. Beski, S. S. M., Swick R. A. and Iji P. A. 2015. Specialised Protein Products in Broiler Chicken Nutrition: A Review. J. Animal Nutrition. 1:47-53.

Beski, S. S. M., Swick R. A. and Iji P. A. (2015). Specialised Protein Products in Broiler Chicken Nutrition: A Review. J. Animal Nutrition. 1:4753.

Brand, Z., Brand, T. S. and Brown, C. R.. 2003). The effect of dietary and protein levels on production in breeding female ostrich. Br. Poult. Sci. 44:589-606. https://doi.org/10.1080/0 0071660310001618343.

Čičková H., Newton G. L., Lacy R. C., and Kozánek M. (2015). The use of fly larvae for organic waste treatment. Waste Manag. 35:68-80.

Cullere. M., Tasoniero, G., Giaccone, V., MiottiScapin, R., Claeys, E., De Smet. S., and Dalle Zotte, A. (2016). Black soldier fly as dietary protein source for broiler quails : apparent digestibility, excreta microbial load, feed choice, performance, carcass and meat traits. Animal 10: (12) : 1923 - 1930.

Dewi, S.H.C dan Setiohadi, J. (2010). Manfaat Tepung Pupa Ulat Sutra (Bombyx mori) untuk Pakan Puyuh (Coturnix coturnix japonica) Jantan. Jurnal AgriSains. I (1).

Dewi, D.R.R., Wibowo, S.B. dan Sulistyowati, N.W.. (2017). Analisis Hubungan Margin Kontribusi sebagai Alat Bantu Perencanaan Laba pada Industri Gamelan Margo Laras Kauman Magetan Periode 2014 - 2016. The 9th FIPA : Forum Ilmiah Pendidikan Akuntansi. Universtas PGRI. Madiun. 
Hopley, D. (2015). The evaluation of the potential of Tenebrio molitor, Zophobas morio, Naophoeta cinerea, Blaptica dubia, Gromphardhina portentosa, Periplaneta americana, Blatta lateralis, Oxyhalao duesta and Hermetia illucens for use in poultry feeds. MSc Diss. University of Stellenbosch, Stellenbosch. https://pdfs.semanticscholar.org/d791/ dadd1ea5de686956e8c2493d1801f7b86a57.pdf

Józefiak. D, and R. M. Engberg. (2015). Insects As Poultry Feed. European symposium on Poultry Nutrition, 24-27 August, Prague, Czech Republic.

Kusriningrum, R. S. (2008). Perancanan Percobaan. Airlangga University Press. Surabaya. 15.

Li Q., Zheng L., Qiu N., Cai H., Tomberlin J. K., and Yu Z. (2011). Bioconversion of dairy manure by Black Soldier Fly (Diptera: Stratiomyidae) for biodiesel and sugar production. Waste Manag. 31:1316-1320.

Okah, U. and Onwujiariri, E. B. (2012). Performance of finisher broiler chickens fed maggot meal as a replacement for fish meal. J. Agri. Technol., 8(2): 471-477.

Permatahati. D., Mutiara R. dan Astuti. D.A. (2018). Effect of Cricket Meal (Gryllus bimaculatus) on Production and Physical Quality of Japanese Quail Egg. Tropical Animal Science Journal, April 2019, 42(1):53-58

Rahmasari, R., Sumiati, and Astuti, D.A.. (2014). The effect of silkworm pupae (Bombyx mori) meal to subtitute fish meal on production and physical quality of quail eggs (Coturnix coturnix japonica). J. Indonesian Trop. Anim. Agric. 39: 180- 187.

Santos, G.C, E. A. Gracia, J. A. V. Filho, A. B. Molino. K. Pelica. and D. A. Berto. (2016). Peformance of Japanese Quails Fed with Low-Proteine and Isoleucine. Acta Scientisrum. A.Sci 38(2): 219 -225 .
Suroso, U. Kalsum dan M.F Wadidi. (2016). Pengaruh Penambahan Probiotik Enkapsulasi terhadap Konsumsi Pakan, Produksi Telur dan Efisiensi Pakan pada Burung Puyuh. J.Peternakan 1(2):13-17.

Tugiyanti. E., Rosidi., dan Anam. A. K. (2017). Pengaruh Tepung Daun Sukun (Artocarpus altilis) terhadap Produksi dan Kualitas Telur Puyuh (Coturnix-coturnic japonica. Agripet 17(2): 121-131.

Veldkamp, T. and Bosch, G. (2015). Insects: a proteinrich feed ingredient in pig and poultry diets. Anim. Front. 5(2): 45-50.

Vrabec. V., Kulma.M., and Cocan. D. 2015. Insects as an Alternative Protein Source for Animal Feeding : A Short Review about Chemical Composition. Bulletin UASVM Animal Science and Biotechnologies 72(2) : $116-126$.

Wardhana, A.H. 2016. Black Soldier Fly (Hermetia illucens) sebagai Sumber Protein Alternatif untuk Pakan Ternak. WARTAZOA. 26(2);69 -78 .

Widjiastuti, T. R., Wiradimaja. R., and Rusmana. D. 2014. The effect of substitution of fish meal by black soldier fly (Hermetia illucens) maggot meal in the diet on production performance of quail. D. Anim. Sci. 57:125 -129 .

Wu, G., Wu, Z., Dai, Z., Yang, Y., Wang, W., Liu, C., Wang, B., Wang, J. and Yin, Y. (2013). Dietary requirements of "nutritionally non-essential amino acids" by animals and humans. Amino Acids. 44(4): 1107-1113.

Wu, G., 2014. Dietary requirements of synthesizable amino acids by animals: a paradigm shift in protein nutrition. J. Anim. Sci. Biotechnol. 5(1): $1-34$. 